\title{
Carnitine inhibits arachidonic acid turnover, platelet function, and oxidative stress
}

\author{
P. PIGNATELLI, ${ }^{1}$ L. LENTI, ${ }^{1}$ V. SANGUIGNI, ${ }^{3}$ G. FRATI, ${ }^{2}$ I. SIMEONI, ${ }^{1}$ \\ P. P. GAZZANIGA, ${ }^{1}$ F. M. PULCINELLI,${ }^{1}$ AND F. VIOLI ${ }^{1}$ \\ ${ }^{1}$ Dipartimento di Medicina Sperimentale e Patologia, Università di Roma La Sapienza, \\ 00185 Rome; ${ }^{2}$ Istituto di Chirurgia Toracica e Cardiovascolare, Università di Siena, 0577 Siena; \\ and ${ }^{3}$ Dipartimento di Medicina Interna, Università di Roma Tor Vergata, 00100 Rome, Italy
}

Submitted 20 March 2002; accepted in final form 5 August 2002

\begin{abstract}
Pignatelli, P., L. Lenti, V. Sanguigni, G. Frati, I. Simeoni, P. P. Gazzaniga, F. M. Pulcinelli, and F. Violi. Carnitine inhibits arachidonic acid turnover, platelet function, and oxidative stress. Am J Physiol Heart Circ Physiol 284: H41-H48, 2003. First published September 5, 2002; 10.1152/ajpheart.00249.2002.-Carnitine is a physiological cellular constituent that favors intracellular fatty acid transport, whose role on platelet function and $\mathrm{O}_{2}$ free radicals has not been fully investigated. The aim of this study was to seek whether carnitine interferes with arachidonic acid metabolism and platelet function. Carnitine $(10-50 \mu \mathrm{M})$ was able to dose dependently inhibit arachidonic acid incorporation into platelet phospholipids and agonist-induced arachidonic acid release. Incubation of platelets with carnitine dose dependently inhibited collagen-induced platelet aggregation, thromboxane $\mathrm{A}_{2}$ formation, and $\mathrm{Ca}^{2+}$ mobilization, without affecting phospholipase $\mathrm{A}_{2}$ activation. Furthermore, carnitine inhibited platelet superoxide anion $\left(\mathrm{O}_{2}^{-}\right)$formation elicited by arachidonic acid and collagen. To explore the underlying mechanism, arachidonic acid-stimulated platelets were incubated with NADPH. This study showed an enhanced platelet $\mathrm{O}_{2}^{-}$formation, suggesting a role for NADPH oxidase in arachidonic acid-mediated platelet $\mathrm{O}_{2}^{-}$production. Incubation of platelets with carnitine significantly reduced arachidonic acid-mediated NADPH oxidase activation. Moreover, the activation of protein kinase $\mathrm{C}$ was inhibited by $50 \mu \mathrm{M}$ carnitine. This study shows that carnitine inhibits arachidonic acid accumulation into platelet phospholipids and in turn platelet function and arachidonic acid release elicited by platelet agonists.
\end{abstract}

oxygen free radicals

CARNITINE is a small water-soluble molecule that plays an important role in membrane phospholipid fatty acid turnover $(4,37)$. This molecule is essential for oxidation of fatty acids, which occurs via translocation of long-chain acyl carnitine-CoA into the mitochondrial matrix where acyl-carnitines are reconverted to the respective acyl-CoAs $(18-20,26)$. For this reason, carnitine plays a crucial role in muscle function, as suggested by the association between intracellular levels and heart failure $(27,37)$. However, the role played by

Address for reprint requests and other correspondence: F. Violi, Univ. of Rome "La Sapienza", Divisione IV Clinica Medica, Policlinico Umberto I, Viale del Policlinico, 00185 Rome, Italy (E-mail: Francesco.Violi@uniroma1.it). carnitine on fatty acid turnover could elicit other biological effects on cell function. Among the fatty acids, arachidonic acid (AA) has a key role in the activation of platelets (5) inasmuch as it is converted to the potent vasoconstrictor and aggregating agent thromboxane $\mathrm{A}_{2}$ by the cycloxygenase enzyme (5). AA metabolism activation plays also an important role in the formation of oxygen free radicals likely via stimulation of NADPH oxidase (14). Oxygen free radicals, which include superoxide anion $\left(\mathrm{O}_{2}^{-}\right)$, hydroxyl radical, and other oxygen species, such as singlet oxygen, are highly reactive substances that react with lipids, proteins, and DNA, provoking irreversible changes of their biomolecular structure (16). There is a growing body of evidence that oxygen free radicals are produced by platelets, leukocytes, and endothelial cells $(13,16,30,40)$, where they may exert different functions. Thus they are intermediate metabolites of several enzymatic reactions, are involved in the posttranslational protein turnover and play a role on the control of signal transduction (13). Overproduction of oxygen free radicals may have important pathophysiological implications. Production of oxygen free radicals by macrophages, endothelial cells, and platelets is important in favoring low-density lipoprotein oxidation, and, in turn, low-density lipoprotein accumulation within the vessel wall; this sequence of events seems to be crucial for initiation and progression of atherosclerosis (17).

Because carnitine acts by reacting with fatty acids giving formation of carnitine-arachidonyl-CoA, we speculated that this mechanism could influence platelet function via interference with AA metabolism. We report for the first time that carnitine affects AA metabolism, and, in turn, platelet activation and oxidative stress.

\section{MATERIALS AND METHODS}

Platelet preparation. Blood mixed with $0.13 \mathrm{mM}$ sodium citrate (ratio 9:1) was collected from healthy volunteers (nonsmokers) who had not ingested any drugs known to interfere with platelet function for at least 15 days and had fasted for at least $12 \mathrm{~h}$. All participants gave informed consent.

The costs of publication of this article were defrayed in part by the payment of page charges. The article must therefore be hereby marked "advertisement" in accordance with 18 U.S.C. Section 1734 solely to indicate this fact. 
A

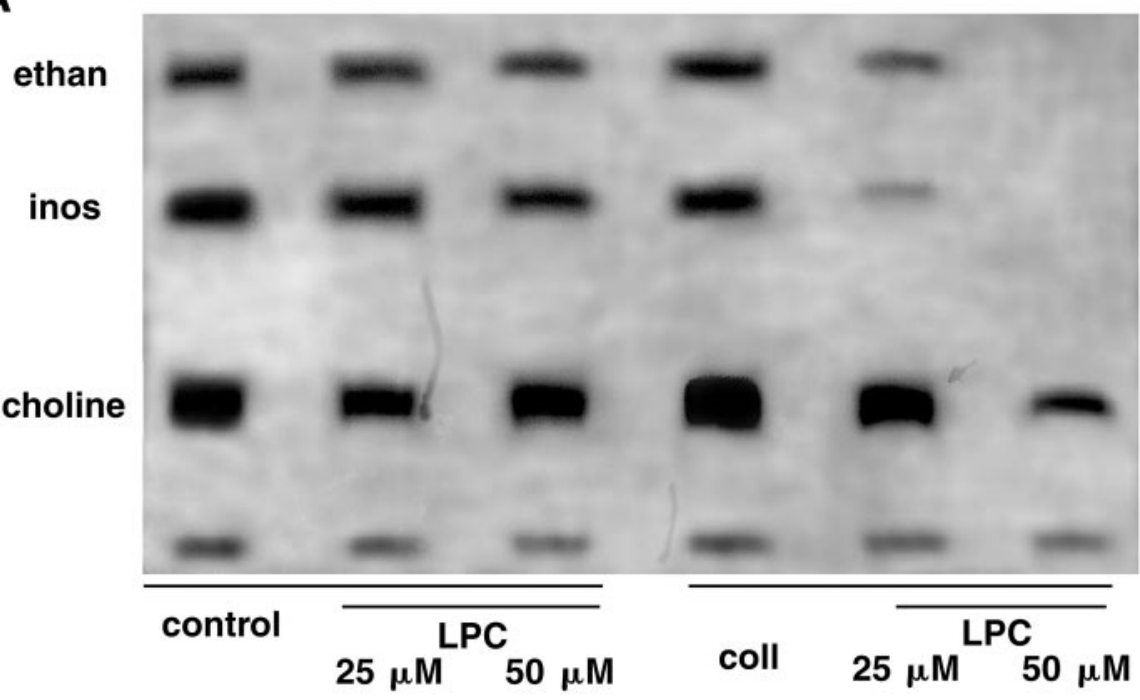

B

Fig. 1. Effect of L-propionyl carnitine (LPC) on $\left[{ }^{14} \mathrm{C}\right]$ arachidonic acid (AA) incorporation into phospholipids. $\left[{ }^{14} \mathrm{C}\right] \mathrm{AA}$ incorporation into phosphatidyl inositol (inos), ethanolamine (ethan), and choline in collagen-stimulated (coll; $2 \mu \mathrm{g} / \mathrm{ml})(A)$, AA-stimulated $(0.5$ $\mu \mathrm{M})(B)$, and thrombin (Thr; $0.1 \mathrm{U} / \mathrm{ml}$ )-stimulated platelets $(C)$ treated with or without LPC $(10-50 \mu \mathrm{M})$. Values are the means of five experiments.

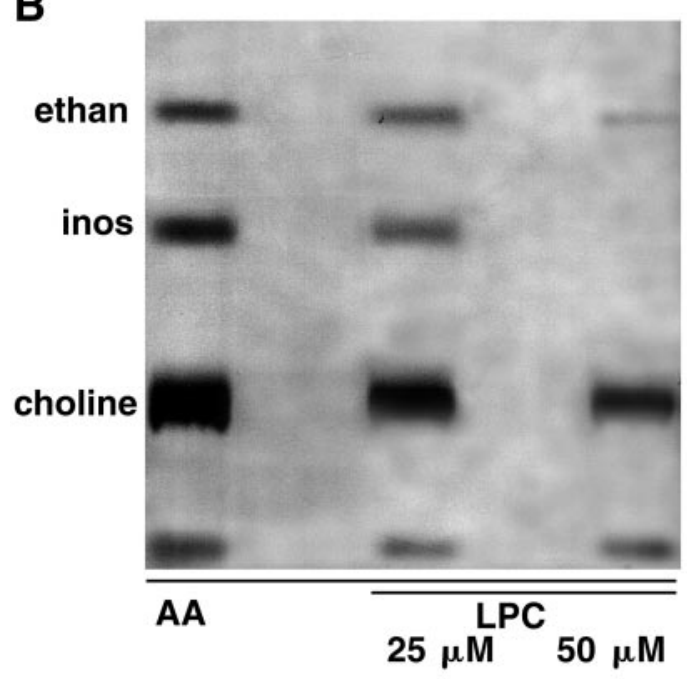

C

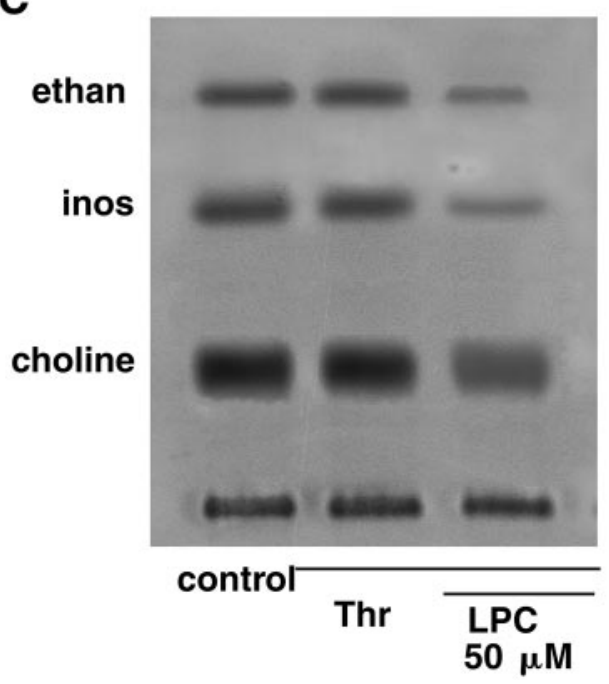


Table 1. Effect of LPC on $\left[{ }^{14} C\right] A A$ incorporation in phospholipids, PI, PC, and PE

\begin{tabular}{|c|c|c|c|c|c|c|c|c|}
\hline ROI & \multicolumn{2}{|c|}{ Thrombin } & \multicolumn{3}{|c|}{ Collagen } & \multicolumn{3}{|c|}{ Arachidonic Acid } \\
\hline $\mathrm{PE}$ & $1.22 \pm 0.10$ & $0.54 \pm 0.20 *$ & $1.01 \pm 0.01$ & $0.72 \pm 0.04^{*}$ & $0.46 \pm 0.05^{*}$ & $0.90 \pm 0.02$ & $0.68 \pm 0.03^{*}$ & $0.29 \pm 0.01 *$ \\
\hline $\mathrm{PC}$ & $1.40 \pm 0.08$ & $0.98 \pm 0.30 *$ & $1.13 \pm 0.30$ & $1.00 \pm 0.01^{*}$ & $0.76 \pm 0.1^{*}$ & $1.14 \pm 0.20$ & $1.02 \pm 0.01^{*}$ & $0.82 \pm 0.03^{*}$ \\
\hline
\end{tabular}

Results are means $\pm \mathrm{SE}$ for 5 experiments. ROI, ratio of incorporation; PI, phosphatidyl inositol; PC, phosphatidyl choline; PE, phosphatidyl ethanolamine; LPC, L-propionyl carnitine. Platelets were stimulated by thrombin $(0.1 \mathrm{U} / \mathrm{ml})$, collagen (4 $\mu \mathrm{g} / \mathrm{ml})$, or arachidonic acid $(0.5 \mathrm{mM})$. Values are expressed as ROI. ${ }^{*} P<0.005$, each sample vs. control.

Platelets were separated from plasma and suspended in $\mathrm{Ca}^{2+}$-free Tyrode buffer containing $0.2 \%$ bovine serum albumin, $5 \mathrm{mM}$ glucose, and $10 \mathrm{mM}$ HEPES (pH 7.35), according to our previous study (28).

$\left[{ }^{14}\right.$ C $] A A$ incorporation into phospholipids. The AA metabolism was studied by prelabeling with $\left[{ }^{14} \mathrm{C}\right] \mathrm{AA}$ and activating platelets treated with or without L-propionyl carnitine (LPC) $\left(25-50 \mu \mathrm{M}, 30 \mathrm{~min}, 37^{\circ} \mathrm{C}\right.$ ) (generously provided by Sigma Tau) with collagen, AA, or thrombin $\left(2 \mathrm{~min}, 37^{\circ} \mathrm{C}\right)$ as above described (28). Lipid extraction was performed as described by Folch et al. (10).

Separation of the individual phospholipids was performed according to the method described by Holub et al. (15) using a one-dimensional thin-layer chromatographic system with Merck silica gel plates.

The solvent system consisted of chloroform-methanol-acetic acid-water (50:37.5:3.5:2 vol/vol/vol/vol). The $R_{f}$ value of phospholipid classes corresponded with those of standard phospholipids. Phospholipid identities were further determined with the use of ninhydrin and molybdenum blue.

Distribution of AA and the amount of labeled AA were determined by autoradiography; X-ray film (Kodak X-Omat AR) was placed on the top of the plate and exposed for 7 days. The developed spots were calculated by densitometric analysis on a NIH Image $1.62 f$ analyzer, and the amount of incorporated $\left[{ }^{14} \mathrm{C}\right] \mathrm{AA}$ in each lane was determined by dividing the area of each spot by the same area of control unstimulated phospholipid lane; the value was expressed as a ratio of incorporation.

AA release. $\left[{ }^{14} \mathrm{C}\right] \mathrm{AA}$ release was studied by prelabeling the platelets with $\left[{ }^{14} \mathrm{C}\right] \mathrm{AA}$, as previously described (28). Briefly, samples of $\left[{ }^{14} \mathrm{C}\right] \mathrm{AA}-$ labeled platelets were preincubated with or without LPC $(10-50 \mu \mathrm{M})$ and then stimulated with AA $(0.5 \mathrm{mM})$, collagen $(2 \mu \mathrm{g} / \mathrm{ml})$, or thrombin $(0.1 \mathrm{U} / \mathrm{ml})$. After 1 min, the reaction was stopped by adding a solution containing $5 \mathrm{mmol} / \mathrm{L} \mathrm{EDTA}, 5 \mathrm{mmol} / \mathrm{l}$ theophylline, and $0.2 \mu \mathrm{g} / \mathrm{ml}$ prostaglandin $\mathrm{E}_{1}$. After centrifugation for $3 \mathrm{~min}$ at $5,000 \mathrm{~g}$, the percentage of $\left[{ }^{14} \mathrm{C}\right] \mathrm{AA}$ released into the supernatant was determined by liquid scintillation counting of $100-\mu l$ aliquots.
In vitro aggregation tests. In vitro maximal percentage of platelet aggregation was evaluated according to our previous study (29). AA $(0.5-2 \mathrm{mM})$, collagen $(2 \mu \mathrm{g} / \mathrm{ml})$, and thrombin $(0.1 \mathrm{U} / \mathrm{ml})$ were used as agonists; platelets $(2 \times$ $10^{8} / \mathrm{ml}$ ) were preincubated with or without the addition of LPC (10-50 $\mu \mathrm{M})\left(30 \mathrm{~min} 37^{\circ} \mathrm{C}\right)$ before the activation. The lag phase of the aggregation induced by collagen $(2 \mu \mathrm{g} / \mathrm{ml})$ was also evaluated.

Production of thromboxane $A_{2}$. Platelets $\left(2 \times 10^{8} / \mathrm{ml}\right)$ were preincubated with or without LPC $(10-50 \mu \mathrm{M})\left(30 \mathrm{~min} 37^{\circ} \mathrm{C}\right)$ and then activated with AA $(0.5 \mathrm{mM})$, collagen $(2 \mu \mathrm{g} / \mathrm{ml})$, or thrombin $(0.1 \mathrm{U} / \mathrm{ml})$; the reaction was stopped after $3 \mathrm{~min}$ with indomethacin $(14 \mu \mathrm{M})$. Thromboxane $\mathrm{A}_{2}$ production was determined with the use of thromboxane $\mathrm{B}_{2}$ ELISA assay kits (28) (Boehringer-Mannheim; Mannheim, Germany).

Platelet cytosolic $\mathrm{Ca}^{2+}$ concentrations. Calcium measurements were performed using the fluorescent indicator dye fura 2 according to the method of Grynkievicz et al. (12). The platelet suspension $\left(2 \times 10^{8} / \mathrm{ml}\right)$ preincubated with or without LPC $(10-50 \mu \mathrm{M})\left(30 \mathrm{~min}\right.$ at $\left.37^{\circ} \mathrm{C}\right)$ was activated with AA $(0.5 \mathrm{mM})$, collagen $(2 \mu \mathrm{g} / \mathrm{ml})$, or thrombin $(0.1 \mathrm{U} / \mathrm{ml})$. The fluorescence changes were then monitored with a fluorimeter (model SFM 25, Kontron; Zurich, Switzerland) set at 340-nm excitation and 510-nm emission.

Detection of $\mathrm{O}_{2}^{-}$released by platelet suspensions and platelet lysates. $\mathrm{O}_{2}^{-}$produced by platelets was measured by using lucigenin chemiluminescence and dihydroethidium cytofluorimetric analysis. The chemiluminescence of lucigenin was detected with a luminometer (Bio-Orbit 1251). The chemical specificity of this light-yielding reaction for $\mathrm{O}_{2}^{-}$was reported by Freedman et al. (11). This method was questioned by Liochev et al. (24), but Afanas'ev et al. (1) documented its validity. Because platelets express endothelial nitric oxide (NO) synthase and collagen is able to induce NO formation (31), a control experiment was performed in the presence of the endothelial NO synthase inhibitor $N^{\mathrm{G}}$-nitro-L-arginine methyl ester (L-NAME; $200 \mu \mathrm{M}$ ) to prevent NO synthesis from impairing $\mathrm{O}_{2}^{-}$detection by lucigenin, as suggested by Vasquez-Vivar et al. (38). Moreover, superoxide dismutase

Table 2. Platelet aggregation, $\mathrm{Ca}^{2+}$ mobilization, and $\mathrm{Tx} \mathrm{A}_{2}$ formation induced by either collagen or arachidonic acid are inhibited in a dose-dependent manner by LPC

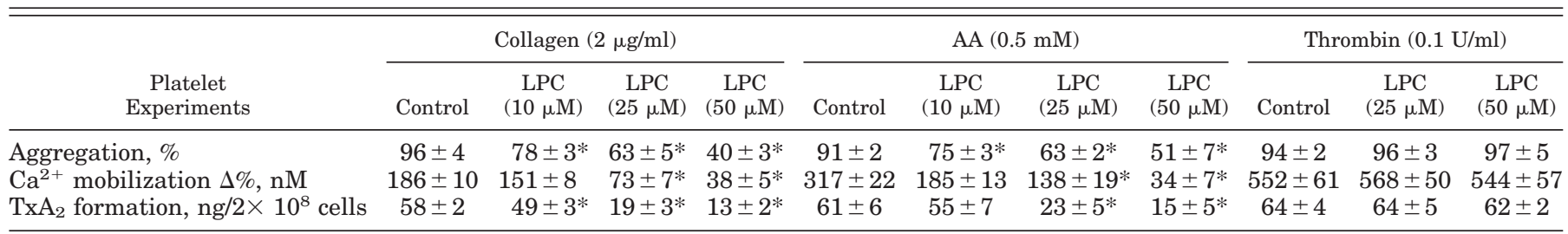

Values are means $\pm \mathrm{SE}$ for five experiments. $\mathrm{TxA}_{2}$, thromboxane $\mathrm{A}_{2} ; \mathrm{AA}$, arachidonic acid. $* P<0.005$ vs. control. 
(300 U/ml) was used to determine the lucigenin specificity of $\mathrm{O}_{2}^{-}$detection (23).

Platelets $\left(5 \times 10^{8} / \mathrm{ml}\right)$ were incubated with or without LPC (10-25-50 $\mu \mathrm{M} 30 \mathrm{~min} 37^{\circ} \mathrm{C}$ ) and in some experiments with the protein kinase $\mathrm{C}$ (PKC) inhibitor RO-31-8220 (10 $\mu \mathrm{M} 10$ min $37^{\circ} \mathrm{C}$ ), and then stimulated with collagen $4 \mu \mathrm{g} / \mathrm{ml}$ or AA $0.5 \mathrm{mM}$. Each sample was added with $0.25 \mathrm{mmol} / \mathrm{l}$ lucigenin, the chemiluminescence obtained at the third minute was measured and $\mathrm{O}_{2}^{-}$production was expressed as nanomoles of $\mathrm{O}_{2}^{-} / 10^{8}$ cells min (23). Samples containing lucigenin plus components (with the exception of platelets) were counted, and these blank values were subtracted from the chemiluminescence signals obtained from platelets stimulated with collagen or AA with and without addition of LPC.

Measurement of platelets NADPH oxidase activity was performed in platelet homogenates, according to the method of Seno et al. (34). Washed platelets were suspended in buffer containing (in $\mathrm{mM}$ ) 50 Tris $\cdot \mathrm{HCl}$ ( $\mathrm{pH}$ 7.4), 1.0 EDTA, 2.0 leupeptin, and 2.0 pepsatin $\mathrm{A}$, and then homogenized. Platelet homogenates were incubated $10 \mathrm{~min} 37^{\circ} \mathrm{C}$ with $25 \mu \mathrm{M}$ NADPH and added with or without $50 \mu \mathrm{M}$ LPC. The assay solution contained $400 \mu \mathrm{l}$ Tyrode buffer and $0.25 \mathrm{mmol} / \mathrm{l}$ lucigenin. After preincubation at $37^{\circ} \mathrm{C}$ for $3 \mathrm{~min}$, the reaction was started by the addition of $100 \mu \mathrm{l}$ of platelet homogenates in presence or less of AA $0.5 \mathrm{mM}$.

The chemiluminescent signal was expressed as relative light units for an average time of $10 \mathrm{~min}$ and corrected by protein concentration (in relative light units per milligram). Protein concentrations were determined by the method of Lowry (25).

The reaction of LPC with $\mathrm{O}_{2}^{-}$was studied in vitro by generating superoxide through pyrogallol autooxidation system. The reaction mixture contained $100 \mu \mathrm{M}$ pyrogallol, 500 $\mu \mathrm{M}$ diethylenetriaminepentacetic acid, and $0.1 \mu \mathrm{M}$ catalase in $50 \mathrm{mM}$ Tris-cacodilate buffer $\mathrm{pH}$ 8.2. The rate of pyrogallol autooxidation was monitored at $420 \mathrm{~nm}$ at $37^{\circ} \mathrm{C}$. LPC was used at concentrations from 5 to $50 \mu \mathrm{M}$.

To further analyze $\mathrm{O}_{2}^{-}$production, we performed a cytofluorimetric experiment using dihydroetidium as a probe (3, 35). Platelet suspension was added with dihydrothidium (HE) (160 $\mu \mathrm{mol} / \mathrm{l}$ final concentration) according to Rothe et al. (32), incubated with or without LPC (10-50 $\mu \mathrm{M} 30 \mathrm{~min}$ $37^{\circ} \mathrm{C}$ ), and stimulated with collagen $4 \mu \mathrm{g} / \mathrm{ml}$ or AA $0.5 \mathrm{mM}$. The reaction was stopped after $3 \mathrm{~min}$ with EGTA $2 \mathrm{mmol} / \mathrm{l}$. Samples were analyzed on a flow cytometer (model XL-MCL, Coulter; Hialeah, FL) equipped with a 480-nm emission argon laser. The flow cytometer was set up to measure logarithmic forward light scatter, which is a measure of particle size, logarithmic $90^{\circ}$ light scatter, which is a measure of cell granularity and red (HE) 590-700 nm fluorescence (LFL1).

The fluorescent signal generated by the probe was expressed as the stimulation index (mean channel fluorescence intensity of stimulated platelets/mean channel fluorescence intensity of unstimulated platelets).

Phosphorylation of platelet proteins. The platelet suspensions $\left(2 \times 10^{8} / \mathrm{ml}\right)$ were incubated for $1 \mathrm{~h}$ at $37^{\circ} \mathrm{C}$ with ${ }^{32} \mathrm{Pi}(2$ $\mathrm{mCi} / \mathrm{ml}$ of cell suspension), separated from plasma proteins and from excess of ${ }^{32} \mathrm{Pi}$ by centrifugation, and suspended in Tyrode buffer containing $0.2 \%$ bovine serum albumin, $5 \mathrm{mM}$ glucose, and $10 \mathrm{mM}$ HEPES (pH 7.35).

$\left[{ }^{32} \mathrm{P}\right]$-labeled platelets were preincubated with or without LPC $(10-50 \mu \mathrm{M})\left(30 \mathrm{~min} 37^{\circ} \mathrm{C}\right)$ and then stimulated with AA $(0.5 \mathrm{mM})$ or collagen $(4 \mu \mathrm{g} / \mathrm{ml})$; the reaction was stopped by addition of an equal volume of twice concentrate Laemmli buffer, followed by incubation at $95^{\circ} \mathrm{C}$ for $5 \mathrm{~min}$.
Protein samples were analyzed by $12 \%$ SDS-PAGE for Western blotting, and proteins were electrotransferred to nitrocellulose membranes.

Immunoblotting was performed with antibody raised against phospholipase $\mathrm{A}_{2}\left(\mathrm{PLA}_{2}\right)$. Immune complexes were detected by enhanced chemiluminescence. The rate of $\mathrm{PLA}_{2}$ and PKC (expressed as phosphorylation of $47-\mathrm{kDa}$ PKCspecific substrate) phosphorylation was analyzed by autoradiography. The developed spots were calculated by densitometric analysis on a NIH Image $1.62 \mathrm{f}$ analyzer, the amount of phosphorylation was determined by dividing the areas of the phosphorylated spots of stimulated platelets by the area of control unstimulated platelets; the value was expressed as ratio of phosphorylation.

Statistical analysis. The results were expressed as means \pm SE. Multiple comparisons among different groups were performed by one-way ANOVA, followed by the Bonferroni test for multiple comparisons. $P$ levels $<0.05$ were considered significant. All calculations were made with statistical analysis software (StatView II, Abacus Concepts; Berkley, CA).

\section{RESULTS}

$\left[{ }^{14} \mathrm{C}\right] \mathrm{AA}$ incorporation into phospholipids. $\left[{ }^{14} \mathrm{C}\right] \mathrm{AA}$ incorporation into phospholipids after $1 \mathrm{~h}$ of incubation was distributed in phosphatidyl inositol (30\%), phosphatidyl choline (41\%), and phosphatidyl ethanolamine $(27 \%)$. No effect of LPC $\left(30 \mathrm{~min} 37^{\circ} \mathrm{C}\right)$ was observed in unstimulated platelets.

Platelet preincubation with LPC $25-50 \mu \mathrm{M}$ (30 min $37^{\circ} \mathrm{C}$ ) dose dependently reduced the amount of AA incorporated into phosphatidyl inositol, phosphatidyl ethanolamine, and phosphatidyl choline in either 4 $\mu \mathrm{g} / \mathrm{ml}$ collagen or $0.5 \mathrm{mM}$ AA or $0.1 \mathrm{U} / \mathrm{ml}$ thrombinstimulated platelets (Fig. 1, $A-C$, and Table 1).

Platelet aggregation. LPC inhibited collagen and AAinduced platelet aggregation depending on the concentration used. LPC (10 and $25 \mu \mathrm{M})$ induced only a partial inhibition of platelet aggregation, whereas 50 $\mu \mathrm{M}$ LPC reduced by $\sim 50 \%$ the maximal percentage of

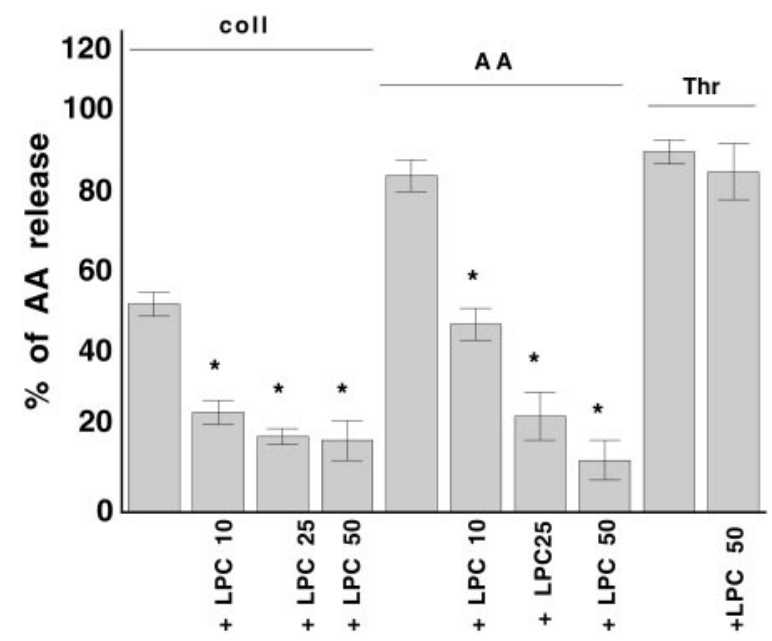

Fig. 2. Effect of LPC on platelet $\left[{ }^{14} \mathrm{C}\right] \mathrm{AA}$ release. Percentage of AA release in $2 \mu \mathrm{g} / \mathrm{ml}$ collagen-, $0.5 \mathrm{mM}$ AA-, and $0.1 \mathrm{U} / \mathrm{ml}$ Thr-stimulated platelets treated with or without LPC $(10-50 \mu \mathrm{M}) . * P<0.01$, data are means $\pm \mathrm{SE}$ of five experiments. 
platelet aggregation. This effect seemed to be specific for collagen and AA because no change was observed with $0.1 \mathrm{U} / \mathrm{ml}$ of thrombin (Table 2). The lag phase of platelet aggregation induced by collagen was dose dependently enhanced by LPC (data not shown).

$\left[{ }^{14} \mathrm{C}\right] A \mathrm{~A}$ release. Platelets stimulated by collagen $(2$ $\mu \mathrm{g} / \mathrm{ml})$ or AA $(0.5 \mathrm{mM})$ released $\left[{ }^{14} \mathrm{C}\right] \mathrm{AA}$, which was inhibited by LPC depending on the concentration used. Conversely, LPC did not affect $\left[{ }^{14} \mathrm{C}\right] \mathrm{AA}$ release induced by thrombin $(0.1 \mathrm{U} / \mathrm{ml})$ (Fig. 2)

Thromboxane $A_{2}$ production. Collagen and AA-induced thromboxane $\mathrm{A}_{2}$ formation was dose dependently inhibited by LPC (Table 2).

Changes in intracellular $\mathrm{Ca}^{2+}$ concentration. In samples stimulated with either collagen $(2 \mu \mathrm{g} / \mathrm{ml})$ or AA $(0.5 \mathrm{mM}) \mathrm{LPC}$ inhibited dose dependently intracellular
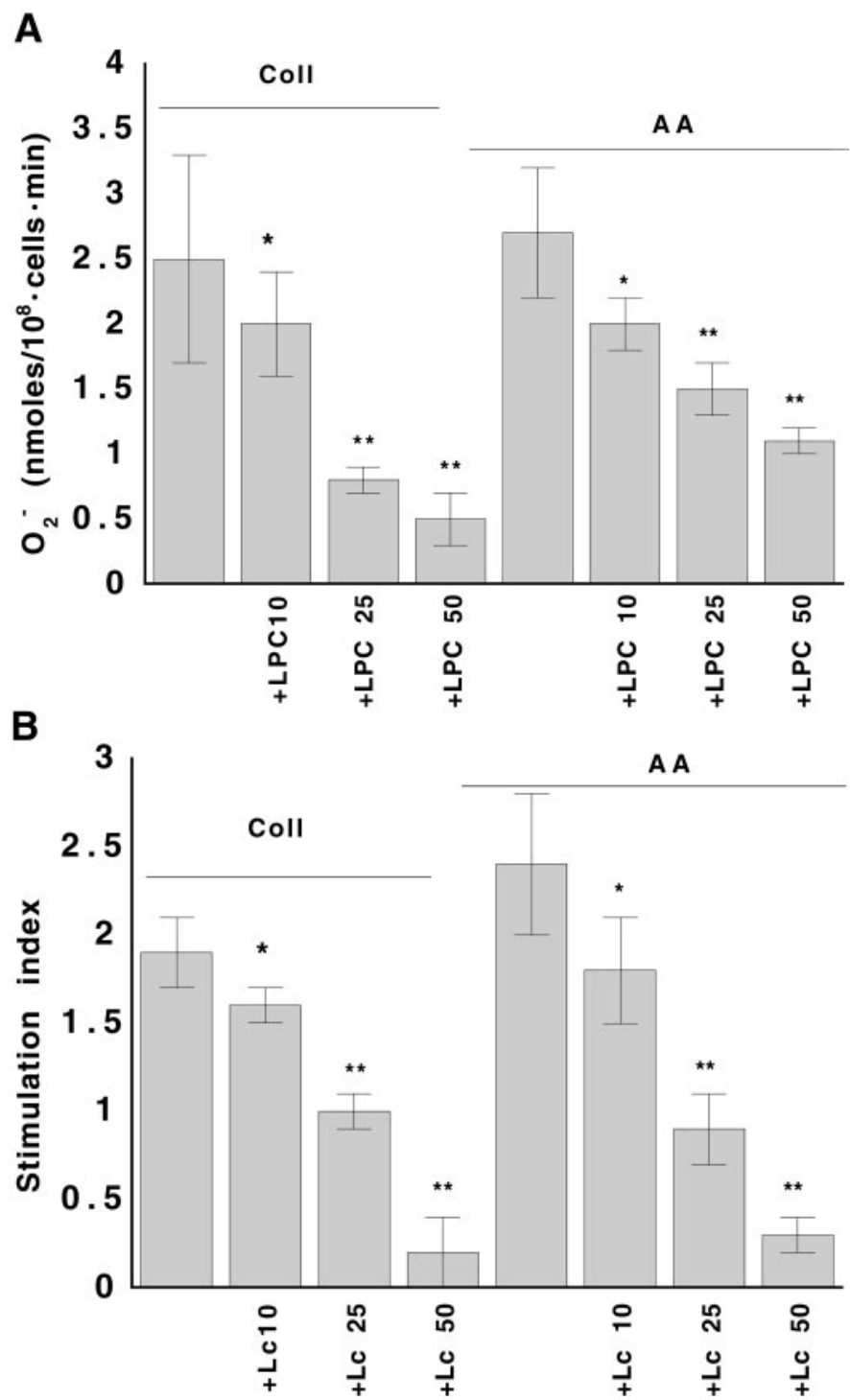

Fig. 3. Effect of LPC on platelet $\mathrm{O}_{2}^{-}$production. $\mathrm{O}_{2}^{-}$production estimated by lucigenin method $(A)$ and dihydroethidium probe $(B) 3$ min after stimulation with $4 \mu \mathrm{g} / \mathrm{ml}$ collagen and $0.5 \mathrm{mM} \mathrm{AA}$ in platelets incubated with or without $10-50 \mu \mathrm{M} \mathrm{LPC}$. $* P<0.05$; ** $P<$ 0.01 , data are expressed as means $\pm \mathrm{SE}$ of five experiments.

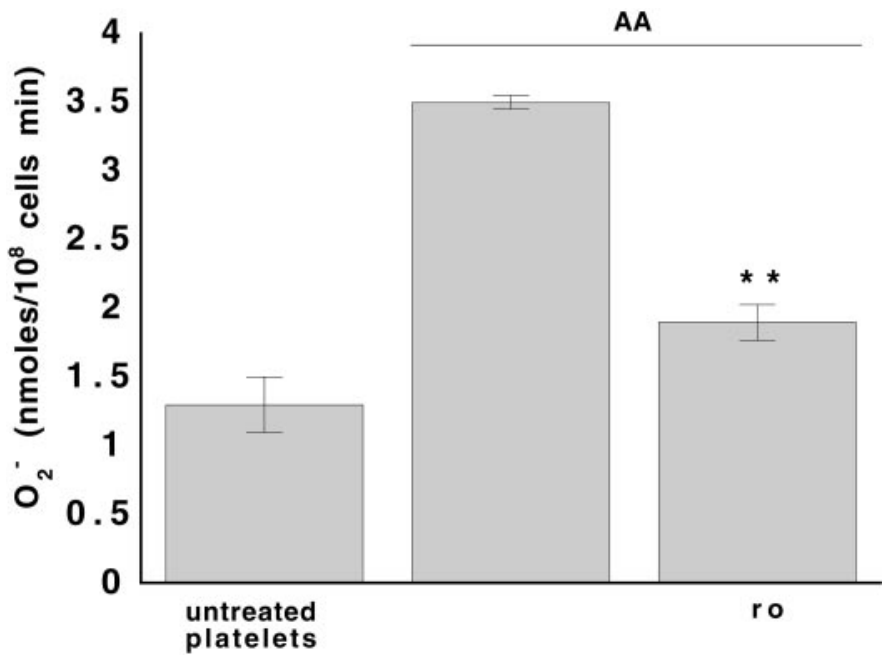

Fig. 4. Protein kinase C (PKC) inhibitor RO-31-8220 (Ro) effect on $\mathrm{O}_{2}^{-}$production. $\mathrm{O}_{2}^{-}$production estimated by lucigenin method 3 min after stimulation with $0.5 \mathrm{mM}$ AA in platelets incubated with or without the PKC inhibitor RO-31-8220 $(10 \mu \mathrm{M})$. ${ }^{* *} P<0.01$, data are expressed as means $\pm \mathrm{SE}$ of five experiments.

$\mathrm{Ca}^{2+}$ mobilization, whereas no changes were observed in $0.1 \mathrm{U} / \mathrm{ml}$ thrombin-stimulated platelets (Table 2 ).

$\mathrm{O}_{2}^{-}$production. $\mathrm{O}_{2}^{-}$production in response to collagen $(4 \mu \mathrm{g} / \mathrm{ml})$ or AA $(0.5 \mathrm{mM})$ was analyzed by luminometer and cytofluorimetric method. A detectable amount of $\mathrm{O}_{2}^{-}$was observed in either collagen or AAstimulated platelets that were inhibited in a dosedependent fashion by LPC (Fig. 3, $A$ and $B$ ). AAinduced $\mathrm{O}_{2}^{-}$production was significantly reduced by the PKC inhibitor RO-31-8220 (10 $\mu \mathrm{M})$ (Fig. 4). No effect of thrombin $(0.1 \mathrm{U} / \mathrm{ml})$ was observed on platelet $\mathrm{O}_{2}^{-}$release (data not shown). No differences in collagen or AA-induced $\mathrm{O}_{2}^{-}$production were observed in samples treated with or without $200 \mu \mathrm{M}$ L-NAME, whereas superoxide dismutase $(300 \mathrm{U} / \mathrm{ml})$ almost completely

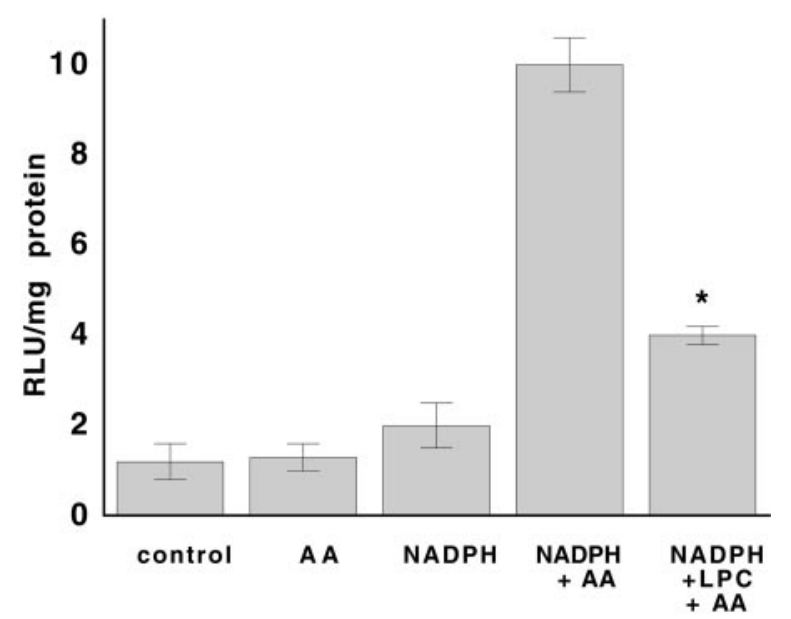

Fig. 5. Effect of LPC on NADH/NADPH oxidase. $\mathrm{O}_{2}^{-}$production estimated by lucigenin method in platelets homogenates in presence of either NADPH $(25 \mu \mathrm{M}), \mathrm{AA}(0.5 \mathrm{mM})$, or both in presence or less of $50 \mu \mathrm{M}$ LPC in relative light units (RLU). $* * P<0.01$, data are expressed as means $\pm \mathrm{SE}$ of five experiments. 
Fig. 6. Effect of LPC on phospholipase $\mathrm{A}_{2}\left(\mathrm{PLA}_{2}\right)$ phosphorylation. A: Western blotting with a mouse monoclonal against $\mathrm{PLA}_{2}(85 \mathrm{kDa})$ of platelet extracts. Collagen $(2 \mu \mathrm{g} / \mathrm{ml})$ and arachidonic acid $(0.5 \mathrm{mM})$ stimulated platelets treated with or without LPC (10$50 \mu \mathrm{M})$. c, control. $B$ : band detected in $A$ by monoclonal against PLA $_{2}$ corresponded to a phosphorylated protein found by autoradiograpy indicating $\mathrm{PLA}_{2}$ activation. A representative example of the five experiments performed is shown.

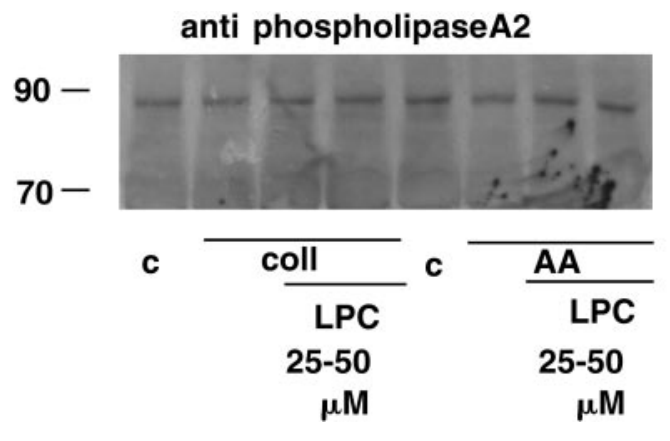

suppressed $\mathrm{O}_{2}^{-}$production (data not shown). The specificity of dihydroethidium probe was analyzed by adding the NO donor sodium nitroprusside $(1 \mathrm{mM})$ that significantly reduced $\mathrm{HE}$ fluorescence as a consequence of $\mathrm{O}_{2}^{-}$subtraction to $\mathrm{NOO}^{-}$formation (data not shown). The rate of pyrogallol auto-oxidation was unaffected even at the highest LPC concentration (data not shown).

When AA was added with NADPH, a significant increase of $\mathrm{O}_{2}^{-}$was observed compared with control: LPC $(50 \mu \mathrm{M})$ significantly decreased AA-mediated $\mathrm{O}_{2}^{-}$ formation (Fig. 5).

Phosphorylation of platelet proteins. We incubated platelet suspension with two concentrations (25-50 $\mu \mathrm{M})$ of LPC and analyzed the PLA 2 activation by its phosphorylation in response to collagen $2 \mu \mathrm{g} / \mathrm{ml}$ or AA $0.5 \mathrm{mM}$; only $50 \mu \mathrm{M}$ LPC slightly affected $\mathrm{PLA}_{2}$ phosphorylation induced by collagen or AA (Fig. 6, Table 3). Conversely, $50 \mu \mathrm{M}$ LPC strongly inhibited both collagen- and AA-mediated PKC activation (Fig. 7, Table 3).

\section{DISCUSSION}

This study shows for the first time that carnitine plays a role in modulating platelet function by interfering with the metabolism of AA. Thus we demonstrated that carnitine reduced incorporation of AA into platelet phospholipids, an effect that is likely dependent upon the central mechanism of action of carnitine (20). In fact, this molecule can react with $\mathrm{AA}$, giving formation of carnitine-arachidonyl-CoA, which, in turn, is degraded by acyl-CoA-hydrolase $(2,20)$.

This phenomenon was particularly evident when free AA increased as a consequence of platelet activation. However, inhibition of AA incorporation into platelet phospholipids was less evident with thrombin likely because of the moderate implication of AA in the pathway of thrombin-stimulated platelets (20). Conversely, carnitine was not able to reduce AA incorporation in resting platelets likely because the concentration of free AA in resting cells is low. (6).

It seems possible to exclude a direct action of carnitine on $\mathrm{PLA}_{2}$ that cleaves AA from $s n$-2-position of phospholipids through an $85-\mathrm{kDa}$ calcium-dependent $\mathrm{PLA}_{2}(5,21,22,33)$. Thus coincubation of collagenstimulated platelets with carnitine reduced platelet AA release but did not significantly affect the activation of $\mathrm{PLA}_{2}$ even at the highest concentration of carnitine used.

The inhibition of AA incorporation into platelet phospholipids is likely to play a pivotal role on changes of platelet function elicited by carnitine. Thus we observed that carnitine induced a significant inhibition of both collagen-induced platelet aggregation and thromboxane $\mathrm{A}_{2}$ formation, two phenomena attributable to a reduced availability of $\mathrm{AA}$ into platelet phospholipids. A reduced but less evident incorporation of $\mathrm{AA}$ into phospholipids was also elicited by carnitine in thrombin-stimulated platelets. This lower effect is in accord with the minor role of $\mathrm{AA}$ in thrombin-stimulated platelets and likely account for the insignificant functional changes observed in thrombin-stimulated platelets treated with carnitine. This finding is in accordance with Triggiani et al. (36), who found no effect of carnitine on thrombin-induced platelet activation.

Previous studies $(16,23,30)$ demonstrated that on stimulation platelets produced oxygen free radicals; however, the mechanism has not been fully elucidated. However, AA metabolism activation could play an important role as aspirin, an inhibitor of cycloxygenase enzyme, and $\mathrm{AACOCF}_{3}$ (arachidonyl trifluoromethyl ketone), a potent inhibitor of $\mathrm{PLA}_{2}$, inhibited and completely suppressed, respectively, the formation of

Table 3. Effect of LPC on agonist-induced PLA $A_{2}$ and PKC phosphorylation

\begin{tabular}{|c|c|c|c|c|c|c|}
\hline ROI & \multicolumn{3}{|c|}{ Collagen } & \multicolumn{3}{|c|}{ Arachidonic Acid } \\
\hline $\mathrm{PLA}_{2}$ & $1.27 \pm 0.02$ & $1.29 \pm 0.03$ & $1.19 \pm 0.08$ & $1.29 \pm 0.06$ & $1.30 \pm 0.02$ & $1.15 \pm 0.03$ \\
\hline
\end{tabular}

Results are expressed as means $\pm \mathrm{SE}$ of 5 experiments. PLA 2 , phospholipase $\mathrm{A}_{2}$; PKC, protein kinase C. PKC activation is expressed as phosphorylation of its specific substrate $(47 \mathrm{kDa})$. Platelets were stimulated with collagen $(2 \mu \mathrm{g} / \mathrm{ml})$ or AA $(0.5 \mathrm{mM})$. Values are expressed as the ratio of phosphorylation. ${ }^{*} P<0.005$ vs. control. 
47-KDa PKCsubstrate phosphopylation $\left({ }^{32} \mathrm{P}\right)$

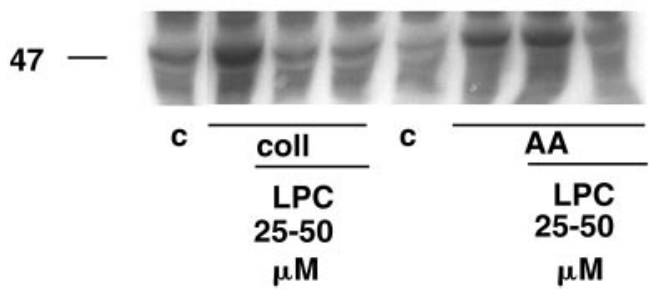

Fig. 7. Effect of LPC on PKC-dependent protein phosphorylation. Proteins electrophoresed by SDS-PAGE; collagen $(2 \mu \mathrm{g} / \mathrm{ml})$ and AA $(0.5 \mathrm{mM})$ stimulated platelets treated with or without LPC (10-50 $\mu \mathrm{M})$. A representative example of five experiments performed is shown.

platelet $\mathrm{O}_{2}^{-}(8,9,38)$. It was unclear how AA metabolism contributed to the formation of $\mathrm{O}_{2}^{-}$. By using the endothelial cell as a source of $\mathrm{O}_{2}^{-}$, Sciose and Sumimoto (33) demonstrated that NADH/NADPH oxidase activation is an important mechanism involved in AA-induced $\mathrm{O}_{2}^{-}$formation. More recently, two constituents of the NADH/NADPH oxidase system, namely p22 $2^{\text {phox }}$ and $\mathrm{p} 67^{\text {phox }}$, have been found in platelets (34). Our data underscored an important role for NADPH oxidase in the AA-mediated platelet $\mathrm{O}_{2}^{-}$production, as coincubation of this enzymatic substrate with AA significantly enhanced platelet $\mathrm{O}_{2}^{-}$production. Carnitine was able to interfere with platelet oxidative stress because it inhibited dose dependently AA-induced $\mathrm{O}_{2}^{-}$ formation. This effect could be explained by the reduced availability of platelet $\mathrm{AA}$, and, in turn, of NADPH oxidase activation; accordingly, carnitine significantly inhibited AA-mediated NADPH oxidase activation.
To explore the mechanism by which carnitine inhibited this system, we investigated whether carnitine influenced the activation of PKC, an enzyme that is known to stimulate NADH/NADPH oxidase (14) and demonstrated that carnitine dose dependently inhibited PKC activation.

The inhibition of platelet $\mathrm{O}_{2}^{-}$production by carnitine may be of biological and clinical relevance due to the key role played by $\mathrm{O}_{2}^{-}$in inactivating $\mathrm{NO}$ (39), a potent vasodilator and antiaggregating substance produced by endothelial cell. $\mathrm{O}_{2}^{-}$is able to rapidly convert $\mathrm{NO}$ to $\mathrm{ONOO}^{-}$, a dangerous oxidant species. Also, inhibition of $\mathrm{O}_{2}^{-}$by carnitine could further contribute to inhibiting platelet aggregation because of the role played by oxygen free radicals in modulating phospholipase $\mathrm{C}$ pathway (28). This suggestion may be supported by demonstrating that carnitine reduced calcium mobilization, which occurs upon thromboxane-dependent phospholipase C activation (7).

Taken together, these data suggest that carnitine may represent an important agent that modulates platelet function and oxidative stress via inhibition of AA incorporation into platelet phospholipids. This could lead to hypothesize a role for this molecule in pathological settings such as heart failure or atherosclerotic disorders associated with enhanced oxidative stress; this suggestion, however, needs to be verified in future study.

In conclusion, we demonstrated that carnitine is an important modulator of intracellular fatty acid transport that inhibits incorporation of $\mathrm{AA}$ into platelet phospholipids. This mechanism elicited a series of functional changes such as inhibition of platelet function and reduced oxidative stress likely via interfer-

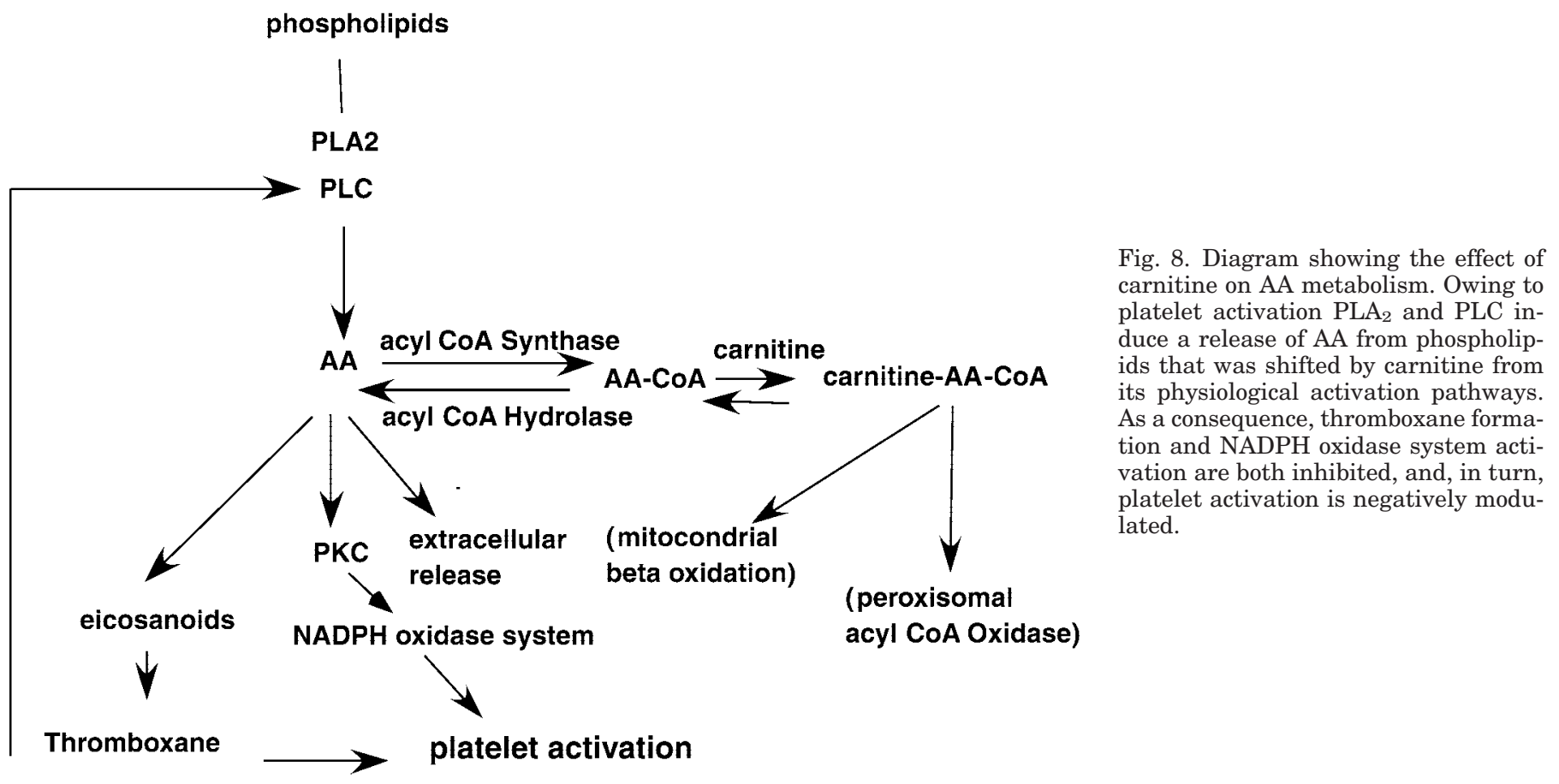


ence with PKC-mediated NADPH oxidation system (Fig. 8). This finding might give new insight to understanding the mechanism leading to enhanced oxidative stress in human pathology.

\section{REFERENCES}

1. Afanas'ev IB, Ostrachovitch EA, and Korkina LG. Lucigenin is a mediator of cytochrome $\mathrm{C}$ reduction but not of superoxide production. Arch Biochem Biophys 366: 267-274, 1999.

2. Arduini A, Mancinelli G, Radatti GL, Dottori S, Molajoni F, and Ramsay RR. Role of carnitine and carnitine palmitoyltransferase as integral components of the pathway for membranephospholipid fatty acid turnover in intact human erythrocytes. J Biol Chem 267: 12673-12681, 1992.

3. Benov L, Sztejnberg L, and Fridovich L. Critical evaluation of the use of hydroethidine as a measure of superoxide anion radical. Free Radic Biol Med 25: 826-831, 1998.

4. Biber LL. Carnitine. Annu Rev Biochem 57: 261-283, 1988.

5. Borsch-Haubold A, Kramer RM, and Watson SP. Cytosolic phospholipase $\mathrm{A}_{2}$ is phosphorylated in collagen- and thrombinstimulated human platelets independent of protein kinase $\mathrm{C}$ and mitogen-activated protein kinase. J Biol Chem 270: 2588525892, 1995.

6. Brash AR. Arachidonic acid as a bioactive molecule. J Clin Invest 107: 1339-1345, 2001.

7. Brass LF and Joseph SK. A role for inositol triphosphate in intracellular $\mathrm{Ca}^{2+}$ mobilization and granule secretion in platelets. J Biol Chem 260: 15172-15179, 1985.

8. Caccese D, Pratico D, Ghiselli A, Natoli S, Pignatelli P, Sanguigni V, Iuliano L, and Violi F. Superoxide anion and hydroxyl radical release by collagen-induced platelet aggregation-role of arachidonic acid metabolism. Thromb Haemost 83: 485-490, 2000.

9. Dana R, Malech HL, and Levy R. The requirement for phospholipase $\mathrm{A}_{2}$ for activation of the assembled NADPH oxidase in humanneutrophils. Biochem J 297: 217-223, 1994.

10. Folch M, Lees M, and Sloane-Slanley M. A simple method for the isolation and purification of total lipids from animal tissues. J Biol Chem 226: 497-506, 1957.

11. Freedman JE and Keaney JF. Nitric oxide and superoxide detection in human platelet. Methods Enzymol 301: 61-70, 1999

12. Grynkiewicz G, Poenie M, and Tsien RY. A new generation of $\mathrm{Ca}^{2+}$ indicators with greatly improved fluorescence properties. $J$ Biol Chem 260: 3440-3450, 1985.

13. Halliwell B. Free radicals, antioxidant, and human disease: curiosity, cause, or consequence. Lancet 344: 721-724, 1994.

14. Henderson LM and Chappel JB. Articles NADPH oxidase of neutrophils. Biochim Biophys Acta 1273: 87-107, 1996.

15. Holub BJ and Skeaff CL. Nutritional regulation of cellular phosphatidyl inositol. Methods Enzymol 141: 234-242, 1987.

16. Iuliano L, Colavita AR, Leo R, Praticò D, and Violi F. Oxygen free radicals and platelet activation. Free Radic Biol Med 22: 999-1006, 1997.

17. Iuliano L, Mauriello NM, Sbarigia E, Spagnoli LG, and Violi F. Radiolabeled native low-density lipoprotein injected into patients with carotid stenosis accumulates in macrophages of atherosclerotic plaque. Circulation 101: 1249-1254, 2000.

18. Johnston CS, Swan PD, and Corte C. Substrate utilization and work efficiency during submaximal exercise in vitamin C depleted-repleted adults. Int J Vitam Nutr Res 69: 41-44, 1999.

19. Kerner $\mathbf{J}$ and Hoppel $\mathbf{C}$. Fatty acid import into mitochondria. Biochim Biophys Acta 1486: 1-17, 2000.

20. Khan WA, Blobe GC, and Hannun YA. Arachidonic acid and free fatty acids as second messangers and the role of protein kinase C. Cell Signal 3: 171-184, 1995.

21. Kramer RM, Johansen B, Hession C, and Pepinsky RB. Protein structure and properties of a secretable phospholipase $\mathrm{A}_{2}$ from human platelets. Adv Exp Med Biol 275: 35-53, 1990.
22. Kramer RM, Robers EF, Manetta JV, Hyslop PA, and Jakubowski JA. Thrombin-induced phosphorylation and activation of $\mathrm{Ca}^{2+}$-sensitive cytosolic phospholipase $\mathrm{A}_{2}$ inhuman platelets. J Biol Chem 268: 26796-26804, 1993.

23. Leo R, Praticò D, Iuliano L, Pulcinelli FM, Ghiselli A, Pignatelli P, Colavita AR, FitzGerald GA, and Violi F. Platelet activation by superoxide anion and hydroxyl radicals intrinsically generated by platelets that undergone anoxia and then reoxygenated. Circulation 95: 885-891, 1997.

24. Liochev SI and Fridovich I. Lucigenin (bis- $N$-methylacridinium) as a mediator of superoxide anion production. Arch Biochem Biophys 337: 115-120, 1997.

25. Lowry OH, Rosembrough NJ, Farr AL, and Randell RJ. Protein measurement with folin phenol reagent. J Biol Chem 193: 265-271, 1951.

26. Martin MA, Gomez MA, Guillen F, Bornstein B, Campos Y, Rubio JC, de la Calzada CS, and Arenas J. Myocardial carnitine and carnitine palmitoyltransferase deficiencies in patients with severe heart failure. Biochim Biophys Acta 15: 1502$1512,2000$.

27. Packer L, Valenza M, Serbinova E, Starke-Reed P, Frost $\mathbf{K}$, and Kagan V. Free radical scavenging is involved in the protective effect of L-propionyl-carnitine against ischemia-reperfusion injury of the heart. Arch Biochem Biophys 288: 533-537, 1991.

28. Pignatelli P, Pulcinelli FM, Lenti L, Gazzaniga PP, and Violi F. Hydrogen peroxide is involved in collagen-induced platelet activation. Blood 91: 484-490, 1998.

29. Pignatelli P, Pulcinelli FM, Lenti L, Gazzaniga PP, and Violi F. Vitamin E inhibits collageninduced platelet activation by blunting hydrogen peroxide. Arterioscler Thromb Vasc Biol 91: 2542-2547, 1999.

30. Praticò D, Luliano L, Alessandri C, Camastra C, and Violi F. Polymorphonuclear leukocyte-derived $\mathrm{O}_{2}^{-}$reactive species activate primed platelets in human whole blood. Am J Physiol Heart Circ Physiol 264: H582-H587, 1993.

31. Radomski MR, Zakar T, and Salas S. Nitric oxides in platelets. Methods Enzymol 296: 88-107, 1996.

32. Rothe $\mathbf{G}$ and Valet $\mathbf{G}$. Flow cytometric analysis of respiratory burst activity in phagocytes with hydroetidine and 2,7-dichlorofluorescin. J Leukoc Biol 47: 440-448, 1990.

33. Sciose A and Sumimoto H. Arachidonic acid and phosphorylation synergistically induce a conformational change of $\mathrm{p} 47 \mathrm{phox}$ to activate the phagocyte NADPH oxidase. J Biol Chem 275: 13793-13801, 2000.

34. Seno T, Inoue N, Gao D, Okuda M, Sumi Y, Matsui K, Yamada S, Hirata K, Kawashima S, Tawa R, Imajoh-Ohmi $\mathbf{S}$, Sakurai H, and Yokoyama M. Involvement of NADH/ NADPH oxidase in human platelet ROS production. Thromb Res 103: 399-409, 2001.

35. Tarpey M and Fridovich L. Methods of detection of vascular reactive species: nitric oxide, superoxide, hydrogen peroxide, and peroxynitrite. Circ Res 89: 224-236, 2001.

36. Triggiani M, Oriente A, Golino P, Gentile P, Battaglia C, Brevetti G, and Marone G. Inhibition of platelet-activating factor synthesis in human neutrophils and platelets by propionyl-L-carnitine. Biochem Pharmacol 58: 1341-1348, 1999.

37. Vanella A, Russo A, Acquaviva R, Campisi A, Di Giacomo C, Sorrenti V, and Barcellona ML. L-propionyl-carnitine as superoxide scavenger, antioxidant, and DNA cleavage protector. Cell Biol Toxicol 16: 99-104, 2000.

38. Vasquez-Vivar J, Hogg N, and Pritchard A Jr. Superoxide anion formation from lucigenin: an electron spin resonance spintrapping study. FEBS Lett 403: 127-130, 1997.

39. Violi F, Marino R, Milite MT, and Loffredo L. Nitric oxide and its role in lipid peroxidation. Diabetes Metab Res Rev 15: 283-288, 1999.

40. Zweier JL, Broderick R, Kuppursamy P, Thompson-Gorman S, and Lutty GA. Determination of the mechanism of free radical generation in human aortic endothelial cells exposed to anoxia and reoxygenation. J Biol Chem 269: 24156-24162, 1994. 